\title{
FORMULASI SEDIAAN SPRAY EKSTRAK ETANOL 96\% BUAH TERUNG UNGU PANJANG (Solanum melongena L.) DAN BUNGA KENANGA (Cananga adorata)TERHADAP KEMATIAN NYAMUK Aedes $s p$
}

Zainal fikri ${ }^{1}$, Fitria Ernawati ${ }^{1}$, Yunan Jiwintarun ${ }^{1}$

${ }^{1}$ Prodi DIII Jurusan Analis Kesehatan, Poltekkes Kemenkes Mataram

\begin{tabular}{l} 
Article Info \\
\hline Article history: \\
Received Jan $13^{\text {th }}, 2020$ \\
Revised Feb $18^{\text {th }}, 2020$ \\
Accepted Feb $19^{\text {th }}, 2020$ \\
\hline
\end{tabular}

Keyword:

Aedes sp.

long purple eggplants ( solanum melongena $L$.),

canangaflower (cananga adorata), ethanol extract $96 \%$, spray formulation.

\begin{abstract}
Efforts to prevent dengue fever can be done by controlling the Aedes aegypti mosquito population, which requires natural pesticides that are safe for the environment and easily accessible to the community. Cananga flower (Cananga odorata) can cause the death of Ae larvae. aegypti because there are substances or compounds that can kill Aedes aegypti larvae, some substances or compounds that play an important role in canangaflowers in killing Aedes aegypti larvae. The purpose of this study was to determine the effectiveness and effect of a $96 \%$ ethanol extract of long purple eggplant (Solanum melongena L.) spray formulation and $100 \%$ cananga flower oil (Cananga adorata) on the death of Aedes sp. Research Design Post Test Only Control Group Design). Treatment using 3 formulations of a combination of spray extracts of ethanol extract of purple eggplant (Solanummelongena L.) concentration of $100 \%$ and cananga flower oil (Cananga adorata) 100\% with a ratio of 1:2, 1: 1 and 2. Data collected in the form of percentage of mosquito deaths, LC 50 and LC 90 from Aedes mosquitoes on the variation of contact time (1 hour, 2 hours, 3 hours, 4 hours, 5 hours, 6 hours, 7 hours, 8 hours, 9 hours, 10 hours, 11 hours, 12 hours, 24 hours and 72 hours). The results showed that the formulation of a combination of spray extracts of ethanol extract of purple eggplant (Solanum melongena L.) $100 \%$ and canang a flower oil (Cananga adorata) $100 \%$ based on contact time showed a significant value (p) of $0.0000<\alpha 0.05$. Formulation F2 Letal Concentration $50 \%$ (LC50) and Letal Concentration 90\% (LC90) also occur at 5 hour contact time intervals with 6 hours, where at 5 hour contact time there are $32 \%$ mosquito deaths and 6 hour contact time there are $96 \%$ mosquito deaths. The F3 Letal Concentration 50\% (LC50) formulation occurs at 4 hour contact time intervals with 5 hours, where at 4 hour contact time there are $33 \%$ of mosquito deaths and 5 hour contact time there are $84 \%$ mosquito deaths. The formulation of a combination of spray form ethanol extract of purple eggplant fruit (Solanum melongena L.) concentration of $100 \%$ and cananga flower oil (Cananga adorata) $100 \%$ of the distillation results / distillation is very effective in killing Aedes Sp mosquitoes with the most effective concentration is formulation 3. LC50 and LC90 for F1 and F2 are at contact time intervals of 5 hours with 6 hours, while the F3 LC50 formulation is at contact time intervals of 4 hours with 5 hours, and LC90 are at contact time intervals of 5 hours with 6 hours. The formulation of a combination of spray form ethanol extract of purple eggplant fruit (Solanummelongena L.) 100\% concentration and canangaflower oil (Cananga adorata) $100 \%$ is very effective in killing off mosquitoes of Aedes $S p$.
\end{abstract}

Copyright $($ J Jurnal Analis Medika Bio Sains All rights reserved. 
Upaya pencegahan penyakit deman berdarah dapat dilakukan dengan cara pengendalian populasi nyamuk Aedes aegypti, yang memerlukan pestisida alami yang aman terhadap lingkungan dan mudah didapat masyarakat. Bunga Kenanga (Cananga odorata) dapat menyebabkan kematian larva Ae. aegypti karena terdapat zat-zat atau senyawa yang dapat mematikan larva Aedes aegypti, beberapa zat atau senyawa yang berperan penting di dalam bunga kenanga dalam mematikan larva Aedes aegypti. Tujuan dari penelitian ini untuk mengetahui efektivitas dan pengaruh formulasi kombinasi sediaan spray ekstrak etanol $96 \%$ buah terung ungu panjang (Solanum melongena L.)100\% dan minyak bunga kenanga (Cananga adorata) 100\% terhadap kematian nyamuk Aedes sp. Desain penelitian Post Test Only Control Group Design). Perlakuan menggunakan 3 formulasi kombinasi sediaan spray ekstrak etanol buah terung ungu (Solanum melongena L.) konsentrasi 100\% dan minyak bunga kenanga (Cananga adorata) 100\% dengan perbandingan 1:2, 1:1 dan 2. Data yang dikumpulkan berupa persentase kematian nyamuk, LC 50 dan LC 90 dari nyamuk Aedes pada variasi waktu kontak (1 jam, 2 jam, 3 jam, 4 jam, 5 jam, 6 jam, 7 jam, 8 jam, 9 jam, 10 jam, 11 jam, 12 jam, 24 jam dan 72 jam). Hasil penelitian menunjukkan bahwa formulasi kombinasi sediaan spray ekstrak etanol buah terung ungu (Solanum melongena L.) $100 \%$ dan minyak bunga kenanga (Cananga adorata) $100 \%$ dari berdasarkan waktu kontak menunjukkan nilai signifiknsi (p) sebesar 0,0000< $\alpha 0,05$. Formulasi F2 Letal Concentration 50\% (LC50) dan Letal Concentration 90\% (LC90) juga terdapat pada interval waktu kontak 5 jam dengan 6 jam, dimana pada waktu kontak 5 jam terdapat 32\% kematian nyamuk dan waktu kontak 6 jam terdapat 96\% kematian nyamuk. Formulasi F3 Letal Concentration 50\% (LC50) terdapat pada interval waktu kontak 4 jam dengan 5 jam, dimana pada waktu kontak 4 jam terdapat 33\% kematian nyamuk dan waktu kontak 5 jam terdapat 84\% kematian nyamuk. Formulasi kombinasi sediaan spray ekstrak etanol buah terung ungu (Solanum melongena L.) konsentrasi 100\% dan minyak bunga kenanga (Cananga adorata)100\% dari hasil destilasi/penyulingan sangat efektif dalam mematikan nyamuk Aedes Sp dengan konsentrasi paling efektif adalah formulasi 3. LC50 dan LC90 untuk F1 dan F2 terdapat pada interval waktu kontak 5 jam dengan 6 jam, sedangkan formulasi F3 LC50 terdapat pada interval waktu kontak 4 jam dengan 5 jam, dan LC90 terdapat pada interval waktu kontak 5 jam dengan 6 jam. Formulasi kombinasi sediaan spray ekstrak etanol buah terung ungu (Solanum melongena L.) konsentrasi 100\% dan minyak bunga kenanga (Cananga adorata)100\% sangat efektif dalam mematikan nyamuk Aedes $S p$.

Kata kunci: Aedes sp, buah terung ungu panjang (solanum melongena l.), bunga kenanga (cananga adorata), ekstrak etanol 96\%, formulasi sediaan spray.

Copyright $\odot$ Jurnal Analis Medika Biosains (JAMBS)

\section{Pendahuluan}

Upaya pencegahan penyakit deman berdarah dapat dilakukan dengan cara pengendalian populasi nyamuk Aedes aegypti, yang memerlukan pestisida alami yang aman terhadap lingkungan dan mudah didapat masyarakat. Penelusuran dan pengumpulan data dari berbagai jurnal yang menunjukkan hasil ekstrak tanaman yang telah teuji efektif membunuh jentik dan nyamuk Ae. aegypti antara lain minyak atsiri bunga kenanga (Cananga adorata), ekstrak buah bit (Beta vulgaris), daun tembakau (Nicotina tabacum), daun Zodia (Evodia suaveolens) daun kecubung (Patura metel linn aeus), daun dan kulit jeruk purut (Citrus hystrix), daun jeruk nipis (Citrus aurantifolia), daun sirsak (Anona muricata), daun kemangi (Ocinum sanctum) dan batang tanaman tanjung (Mimusops elengi).

Insektisida nabati mengandung senyawa aktif seperti alkaloid, saponin, flavonoid, tannin, triterpenoid dan polifenol dapat dimanfaatkan dalam upaya pengendalian laju pertumbuhan jentik dan nyamuk $A e$. Aegypti (Ira Indriaty Paskalita Bule Sopi, 2016). Hasil penelitian dilakukan secara survey di beberapa kabupaten di Sumatera selatan berhasil menemukan dari 12 jenis tumbuhan yang diuji diperoleh 3 jenis tumbuhan yang berpotensi untuk dikembangkan sebagai sumber biolarvasida yaitu tumbuhan Babadotan, Bunga kenanga dan rimpang lengkuas putih. Dari tumbuhan babadotan diperoleh fraksi aktif berupa fraksi nheksan dan etilasetat. Dari bunga kenanga diperoleh fraksi aktif berupa fraksi $\mathrm{n}$-heksan dan etilasetat, sedangkan dari rimpang lengkuas putih diperoleh fraksi aktif berupa fraksi n-heksana (Erwin N, dkk 2013).

Tanaman kenanga (Cananga odorata) merupakan salah satu jenis tanaman penghasil minyak atsiri yang menghasilkan bau harum. Minyak atsiri merupakan salah satu hasil proses metabolis me dalam tanaman yang disintesis di dalam sel tanaman terbentuk karena reaksi antara berbagai persenyawaan kimia dengan air. Fungsi minyak atsiri pada tanaman adalah memberi bau untuk membantu penyerbukan, media distribusi ke 
biji, dan penolak nyamuk. Minyak atsiri merupakan bahan aktif yang mempunyai kemampuan untuk menolak nyamuk yang mendekati manusia (mencegah terjadinya kontak langsung antara nyamuk dan manusia) sehingga manusia terhindar dari penularan penyakit akibat gigitan nyamuk (Putu et al., 2019)

Penelitian ekstrak bunga kenanga (Canangium odoratum) mempunyai efektivitas larvasida pada larva Ae. aegypti menunjukkan hasil pada konsentrasi 0,02\% kematian larva uji mencapai 96\% di jam ke-24, hasil uji Mann-Whitney bahwa antara kelompok kontrol dengan semua konsentrasi memiliki perbedaan jumlah kematian larva yang secara statistik signifikan. Konsentrasi $0,02 \%$ sangat efektif dalam membunuh larva nyamuk Ae.aegypti. Hasil uji Mann-Whitney untuk lama kontak didapatkan bahwa lama kontak 24 jam memiliki pengaruh yang sangat signifikan terhadap kematian larva Ae.aegypti. Nilai LC50 menunjukkan penurunan nilai konsentrasi seiring peningkatan waktu (jam ke 4-24) yaitu 0,133\% sampai dengan 0,001\%. Untuk nilai LC90 yaitu $0,008 \%$. Sedangkan nilai LT50 menunjukkan penurunan waktu yang dibutuhkan seiring peningkatan konsentrasi (0,0025\%-0,02\%) yaitu dari 15,076 jam sampai 6,701 jam (Listya P, 2014).

Ekstrak kenanga efektif sebagai replensia nyamuk Culex sp (A, n.d.) dari bunga kenanga diperoleh fraksi aktif berupa fraksi n-heksan dan etil asetat. Dari hasil pengamatan yang ada pada tiap fraksi ekstrak kenanga didapatkan hasil bahwa fraksi etil asetat memiliki kemampuan yang cukup baik sebagai biolarvasida, karena mampu membunuh larva hingga 100\%. Sedangkan pada fraksi $\mathrm{n}$-heksan hanya mampu membunuh larva $83,3 \%$. Sedangkan pada fraksi methanol tidak dapat digunakan sebagai biolarvasida karena tidak dapat membunuh larva Ae.aegypti L (Nofyan \& Marisa, 2013).

Kenanga mampu mengusir nyamuk karena baunya yang harum dan khas yang tidak disukai oleh nyamuk serta karena adanya kandungan geraniol, linalol, daneugenol (Widyastuti \& Jannah, 2015). Bunga Kenanga (Cananga odorata) dapat menyebabkan kematian larva Ae. aegypti karena terdapat zat-zat atau senyawa yang dapat mematikan larva Aedes aegypti, beberapa zat atau senyawa yang berperan penting di dalam bunga kenanga dalam mematikan larva Aedes aegypti yaitu minyak atsiri saponin, flavonoida dan poilifenol (Widyastuti \& Jannah, 2015). Penelitian lain yang menggunakan bunga kenanga dan bunga kamboja kuning, dapat berfungsi sebagai penolak nyamuk karena digunakan tanaman bunga kenanga dan kamboja kuning karena tanaman ini mengandung minyak atsiri yang (Hidayati, Suhirman, \& Wahyudiati, n.d.). Bahan alam lain yang berasal dari tanaman yang sekaligus dapat dimanfaatkan sebagai sayur, mudah didapatkan masyarakat dan belum banyak diteliti untuk larvasida adalah adalah buah terung ungu. Buah terung ungu merupakan buah yang berasal dari genus Solanum, mengandung zat aktif yang dapat dimanfaatkan sebagai insektisida.

Berdasarkan teori buah terung ungu diketahui banyak mengandung alkaloid steroid (solasodine, solanine, solanidine), saponin, flavonoid, tanin, kumarin. Kulit buah terung ungu banyak mengandung antosianin serta asam klorogenat (Suhandoyo, Astuti, \& Ratnawati, 2013). Berdasarkan penelitian Saleh (2015) ekstrak etanol buah terung ungu (Solanum melongena) yang diekstrak menggunakan metode maserasi mengandung flavonoid, tanin, glikosida, steroid dan alkaloid. Hasil penelitian terhadap berbagai varietas terung membuktikan bahwa terung ungu memiliki aktivitas antioksidan yang lebih baik dari lima varietas terung lain karena mengandung kadar flavonoid total yang tinggi (Fadlia, 2011). Kadar flavonoid total pada ekstrak etanol terung ungu sebesar 29,35 \pm 0,09 \% b/b Ekuivalen Kuersetin (Islamiyati, 2013). Selain itu, terung ungu juga mengandung alkaloid $0.99 \pm 0.0 \mathrm{mg} / 100 \mathrm{~g}$, tanin $11.34 \pm 0.48 \mathrm{mg} / 100 \mathrm{~g}$, dan saponin 11.63 $\pm 0.29 \mathrm{mg} / 100 \mathrm{~g}$ (Agoreyo, Obansa, \& Obanor, 2012).

Penelitian Agoreyo et al. (2012) tentang perbedaan nutrisi dan fitokimia pada 2 varian buah terung (Solanum melongena) menunjukkan hasil analisis fitokimia pada buah terung varian bulat mengandung alkaloid $1.16 \pm 0.09 \mathrm{mg} / 100 \mathrm{~g}$, tanin $12.82 \pm 0.14 \mathrm{mg} / 100 \mathrm{~g}$, dan saponin $5.34 \pm 0.31 \mathrm{mg} / 100 \mathrm{~g}$. Sedangkan pada buah terung varian oval mengandung alkaloid $0.99 \pm 0.0 \mathrm{mg} / 100 \mathrm{~g}$, tanin $11.34 \pm 0.48 \mathrm{mg} / 100 \mathrm{~g}$, dan saponin $11.63 \pm 0.29 \mathrm{mg} / 100$. Hasil penelitian Anis $\mathrm{N}$ (2018) yang menggunakan buah terung ungu berbentuk oval yang berasal dari perkebunan sayur desa Sembalun Lombok Timur membuktikan bahwa ekstrak buah terung ungu (Solanum melongena L.) disemprotkan ke dalam sangkar nyamuk yang berisi 25 ekor nyamuk Aedes sp. berumur 2 - 5 hari yang didiamkan selama 24 jam, menunjukan hasil konsentrasi ekstrak etanol buah terung ungu (Solanum melongena L.) $80 \%$ menyebabkan $84 \%$ kematian nyamuk Aedes $s p$. Konsentrasi ekstrak etanol buah terung ungu (Solanum melongena L.) $60 \%$ menyebabkan $68 \%$ kematian nyamuk Aedes sp. Konsentrasi ekstrak etanol buah terung ungu (Solanum melongena L.) 40\% menyebabkan 44\% kematian nyamuk Aedes sp.

Hasil penelitian Zaenal dkk (2018) walaupun mampu membuktikan ekstrak etanol 96\% buah terung ungu (Solanum melongena L.) yang berasal dari perkebunan sayur desa Sembalun Lombok Timur menggunakan variasi waktu kontak mampu mematikan nyamuk Aedes $S p$, namun ekstrak terungu ungu menghasilkan aroma yang kurang sedap jika diaplikasikan dalam masyarakat, sehingga perlu penelitian 
lanjutan untuk mengkombinasikan ekstrak terungu ungu dengan bahan alam lainnya yang menghasilkan aroma yang harum dan memiliki efek sebagai larvasida, seperti ekstrak bunga kenanga (Cananga adorata). Formulasi kombinasi antara ekstrak etanol buah terung ungu dan minyak bunga kenanga (Cananga adorata) terutama bagaimanakah efektivitasnya dalam mematikan nyamuk Aedes Sp berdasarkan variasi waktu kontak dan nilai $\mathrm{LC}_{50}$,nilai $\mathrm{LC}_{90}$ belum pernah dilaporkan oleh sebab itu perlu dilakukan penelitian mengenai formulasi sediaan spray ekstrak etanol $96 \%$ buah terung ungu panjang (Solanum melongena L.) dan minyak bunga kenanga (Cananga adorata) terhadap kematian nyamuk Aedes sp"

\section{Metode Penelitian}

Desain penelitian yang digunakan adalah Post Test Only Control Group Design, yaitu desain penelitian yang tidak menggunakan pretest terhadap sampel sebelum perlakuan. Penelitian ini menggunakan 3 perlakuan dan 1 kontrol negatif. Jenis perlakuan dibedakan dengan variasi kombinasi formulasi sediaan spray ekstrak etanol $96 \%$ buah terung ungu dengan konsentrasi 100\% dan minyak bunga kenanga $100 \%$ dari hasil destilasi/penyulingan. Adapun jumlah perlakuannya adalah sebagai berikut : F0 =Kontrol negatif (Aquadest), F1= Formulasi sediaan spray ekstrak etanol buah terung ungu (Solanum melongena L.) konsentrasi 100\% dan minyak bunga kenanga (Cananga adorata)100\% dari hasil destilasi/penyulingan dengan perbandingan 1 : 2, F2=: Formulasi sediaan spray ekstrak etanol buah terung ungu (Solanum melongena L.) konsentrasi 100\% dan minyak bunga kenanga (Cananga adorata)100\% dari hasil destilasi/penyulingan dengan perbandingan $1: 1, \mathrm{~F} 3=$ Formulasi sediaan spray ekstrak etanol buah terung ungu (Solanum melongena L.) konsentrasi 100\% dan minyak bunga kenanga (Cananga adorata) $100 \%$ dari hasil destilasi/penyulingan dengan perbandingan $2: 1$. Uji hayati pengamatan kematian nyamuk di laboratorium dilakukan menurut ketentuan WHO.

Pengamatan dilakukan berdasarkan variasi waktu kontak 1 jam, 2 jam, 3 jam, 4 jam, 5 jam, 6 jam, 7 jam, 8 jam, 9 jam, 10 jam, 11 jam, 12 jam, 24 jam, 48 jam dan 72 jam setiap perlakuan dan kontrol. Porsentase kematian nyamuk dihitung setelah pemaparan perlakuan dan kontrol 1 jam, 2 jam, 3 jam, 4 jam, 5 jam, 6 jam, 7 jam, 8 jam, 9 jam, 10 jam, 11 jam, 12 jam, 24 jam, 48 jam dan 72 jam. Kombinasi formulasi sediaan spray ekstrak etanol buah terung ungu (Solanum melongena L.) konsentrasi 100\% dan minyak bunga kenanga (Cananga adorata)100\% dari hasil destilasi/penyulingan dengan perbandingan 1:2, 1: 1 dan 2 : 1 dikatakan efektif apabila dapat mematikan larva nyamuk di atas $80 \%$ pada pengamatan 72 jam. Untuk memperoleh waktu untuk mematikan separuh dan 95\% populasi dianalisa dengan prediksi interval variasi waktu kontak yang menyebabkan kematian nyamuk Aedes $S p$. Apabila pada pengamatan 72 jam kelompok kontrol terdapat kematian 5 - 20\% maka persentase kematian nyamuk dikoreksi dengan rumus Abbot, dan apabila kematian kontrol di atas $20 \%$ maka uji diulang (WHO,.2014).

Populasi yang digunakan dalam penelitian ini adalah : Seluruh buah terong ungu panjang (Solanum melongena L.) yang di dapatkan dari perkebunan sayur Desa Sembalun Lombok Timur dan Seluruh bunga Kenanga (Cananga adorata) berwarna kuning yang di dapatkan di perkarangan rumah penduduk di lingkungan Cakranegara Kota Mataram. Sampet yang digunakan datampenetitian ini adalah.: Ekstrak etanel 96\% buah terong ungu panjang (Solanum melongena L.) yang di dapatkan dari perkebunan sayur Desa Sembalun Lombok Timur dan Minyak bunga Kenanga (Cananga adorata) berwarna kuning yang di dapatkan di perkarangan rumah penduduk di lingkungan Cakranegara Kota Mataram. Subyek yang digunakan dalam penelitian ini adalah : Nyamuk Aedes sp. dewasa yang didapatkan dari pengembangbiakan telur yang berumur $2-5$ hari. Jumlah nyamuk Aedes sp. dewasa yang didapatkan dari pengembangbiakan telur yang berumur $2-5$ hari yang digunakan dalam penelitian ini merujuk pada pedoman WHO. Hasil pengolahan dan uji statistik yang diperoleh disajikan dalam bentuk tabel dan grafik. Adapun uji statistik yang dilakukan adalah analisis One Way Anova dengan tingkat kepercayaan 96\% $(\mathrm{a}=0.05)$ untuk mengetahui pengaruh atau efektivitas larutan formulasi kombinasi formulasi sediaan spray ekstrak terung ungu dan minyak bunga kenanga dengan perbandingan 1:2, 1:1 dan 2:1 dan kontrol dan nilai Lethal Consentration ( $\mathrm{LC}_{50}$ dan $\mathrm{LC}_{90}$ ) berdasarkan interval kematian dari masing - masing variasi waktu kontak.

\section{Hasil Penelitian dan Pembahasan}

1. Jumlah dan Porsentase (\%) kematian nyamuk Aedes Sp.

Jumlah dan porsentase (\%) kematian nyamuk Aedes sp setelah terpapar larutan formulasi sediaan spray ekstrak etanol buah terung ungu (Solanum melongena L.) konsentrasi 100\% dan minyak bunga kenanga (Cananga adorata) konsentrasi 100\% dari hasil destilasi/penyulingan dengan perbandingan $1: 2,1: 1$ dan 2 : 1 selama 1 jam, 2 jam, 3 jam, 4 jam, 5 jam, 6 jam, 12 jam, 24 jam, dan 72 jam dapat dilihat pada tabel 1. 
Tabel 1 Jumlah dan porsentase (\%) kematian nyamuk Aedes Sp setelah terpapar larutan formulasi sediaan spray ekstrak etanol buah terung ungu (Solanum melongena L.) konsentrasi $100 \%$ dan minyak bunga kenanga (Cananga adorata) konsentrasi $100 \%$ berdasarkan variasi waktu kontak.

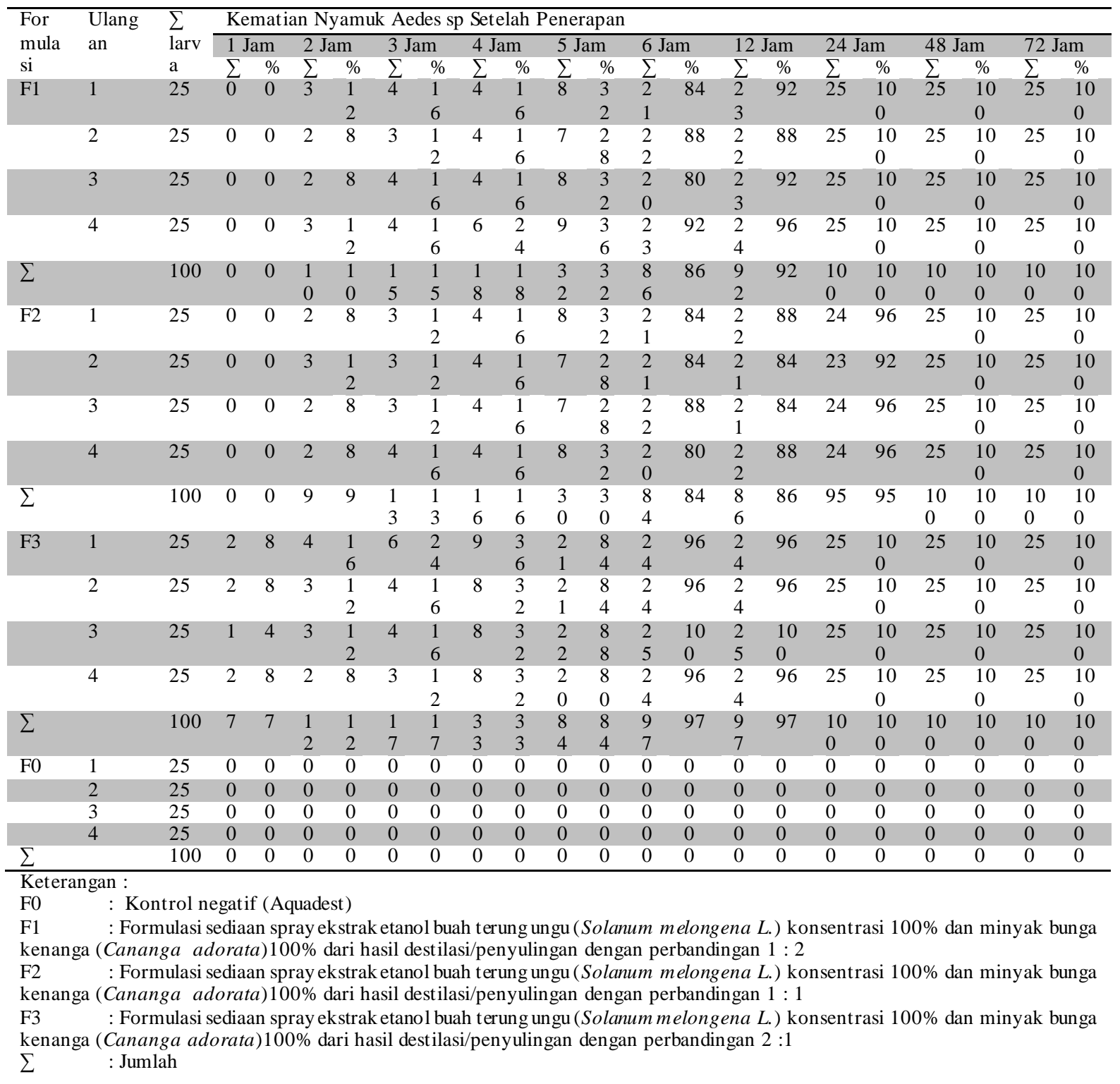

Tabel 1 menunjukkan bahwa kematian nyamuk Aedes sp setelah terpapar larutan formulasi F1 sediaan spray ekstrak etanol buah terung ungu (Solanum melongena L.) konsentrasi $100 \%$ dan minyak bunga kenanga (Cananga adorata) konsentrasi 100\% dari hasil destilasi/penyulingan dengan perbandingan 1:2 yaitu $5 \mathrm{ml}$ ekstrak etanol buah terung ungu (Solanum melongena L.) konsentrasi 100\% dan $10 \mathrm{ml}$ minyak bunga kenanga (Cananga adorata) konsentrasi 100\% dari hasil destilasi/penyulingan mulai menunjukkan kematian setelah terpapar selama 2 jam. Jumlah dan porsentase kematian nyamuk Aedes sp secara berturut turut berdasarkan variasi waktu kontak adalah $0(0 \%)$ pada lama paparan 1 jam, 10 (10\%) pada lama paparan 2 jam, 15 (15\%) pada lama paparan 3 jam, 18 (18\%) pada lama paparan 4 jam, 32 (32\%) pada lama paparan 5 jam, $86(86 \%)$ pada lama paparan 6 jam, $92(92 \%)$ pada lama paparan 12 jam, $100(100 \%)$ pada lama paparan 24 jam, 100 (100\%) pada lama paparan 48 jam dan 100 (100\%) pada lama paparan 72 jam.

Jumlah dan porsentase kematian nyamuk Aedes sp secara berturut - turut berdasarkan variasi waktu kontak adalah 7 (7\%) pada lama paparan 1 jam, 12 (12\%) pada lama paparan 2 jam, 17 (17\%) pada lama paparan 3 jam, 33 (33\%) pada lama paparan 4 jam, 84 (84\%) pada lama paparan 5 jam, 97 (97\%) pada lama 
paparan 6 jam, $100(100 \%)$ pada lama paparan 12 jam, $100(100 \%)$ pada lama paparan 24 jam, $100(100 \%)$ pada lama paparan 48 jam dan $100(100 \%)$ pada lama paparan 72 jam. Kelompok kontrol negative yang di spray dengan aquadest menunjukkan dari paparan 1 jam sampai 72 jam tidak menunjukkan adanya kematian nyamuk Aedes Sp. Tabel 1 juga menunjukkan bahwa pada formulasi F1 Letal Concentration 50\% (LC50) dan Letal Concentration 90\% (LC90) terdapat pada interval waktu kontak 5 jam dengan 6 jam, dimana pada waktu kontak 5 jam terdapat 32\% kematian nyamuk dan waktu kontak 6 jam terdapat $92 \%$ kematian nyamuk. Formulasi F2 Letal Concentration 50\% (LC50) dan Letal Concentration 90\% (LC90) juga terdapat pada interval waktu kontak 5 jam dengan 6 jam, dimana pada waktu kontak 5 jam terdapat 32\% kematian nyamuk dan waktu kontak 6 jam terdapat 96\% kematian nyamuk. Formulasi F3 Letal Concentration 50\% (LC50) terdapat pada interval waktu kontak 4 jam dengan 5 jam, dimana pada waktu kontak 4 jam terdapat 33\% kematian nyamuk dan waktu kontak 5 jam terdapat 84\% kematian nyamuk. Letal Concentration 90\% (LC90) terdapat pada interval waktu kontak 5 jam dengan 6 jam, dimana pada waktu kontak 5 jam terdapat $84 \%$ kematian nyamuk dan waktu kontak 6 jam terdapat $97 \%$ kematian nyamuk. Uji statistik yang untuk mengetahui pengaruh atau efektivitas larutan formulasi kombinasi formulasi sediaan spray ekstrak terung ungu $100 \%$ dan minyak bunga kenanga 100\%dengan perbandingan 1:2, 1:1 dan 2:1 dan kontrol. Adapun hasil uji statistik dapat dilihat pada tabel 2.

Tabel 2. Hasil uji statistik pengaruh formulasi sediaan spray ekstrak etanol buah terung ungu (Solanum melongena L.) konsentrasi $100 \%$ dan minyak bunga kenanga (Cananga adorata) konsentrasi $100 \%$ terhadap kematian nyamuk Aedes $S p$ berdasarkan variasi waktu kontak.

\begin{tabular}{|c|c|c|c|c|}
\hline No. & Konsentrasi & $\begin{array}{l}\text { Waktu } \\
\text { (Jam) }\end{array}$ & Rata-rata & $P$ \\
\hline \multirow[t]{10}{*}{1} & F0 : Kontrol Negatif (Aquadest) & 1 & $0,000 \pm 0,000$ & \multirow{10}{*}{$\begin{array}{l}\text { Konsentrasi } \\
0,0000 \\
\text { Waktu : } 0,0000 \\
\text { Konsentrasi dan } \\
\text { waktu : } 0,0000\end{array}$} \\
\hline & & 2 & $0,000 \pm 0,000$ & \\
\hline & & 3 & $0,000 \pm 0,000$ & \\
\hline & & 4 & $0,000 \pm 0,000$ & \\
\hline & & 5 & $0,000 \pm 0,000$ & \\
\hline & & 6 & $0,000 \pm 0,000$ & \\
\hline & & 12 & $0,000 \pm 0,000$ & \\
\hline & & 24 & $0,000 \pm 0,000$ & \\
\hline & & 48 & $0,000 \pm 0,000$ & \\
\hline & & 72 & $0,000 \pm 0,000$ & \\
\hline \multirow[t]{10}{*}{2} & $\begin{array}{l}\mathrm{F} 1 \text { : Solanum melongena } L \text { dan } \\
\text { Cananga adorata }(1: 2)\end{array}$ & 1 & $0,000 \pm 0,000$ & \\
\hline & & 2 & $2,5000 \pm 0,577$ & \\
\hline & & 3 & $3,7500 \pm 0,500$ & \\
\hline & & 4 & $4,500 \pm 1,000$ & \\
\hline & & 5 & $8,000 \pm 0,816$ & \\
\hline & & 6 & $21,500 \pm 1,290$ & \\
\hline & & 12 & $23,000 \pm 0,816$ & \\
\hline & & 24 & $25,000 \pm 0,000$ & \\
\hline & & 48 & $25,000 \pm 0,000$ & \\
\hline & & 72 & $25,000 \pm 0,000$ & \\
\hline \multirow[t]{10}{*}{3} & $\begin{array}{l}\text { F2 : Solanum melongena } L \text { dan } \\
\text { Cananga adorata }(1: 1)\end{array}$ & 1 & $0,000 \pm 0,000$ & \\
\hline & & 2 & $2,2500 \pm 0,500$ & \\
\hline & & 3 & $3,2500 \pm 0,500$ & \\
\hline & & 4 & $4,000 \pm 0,000$ & \\
\hline & & 5 & $7,500 \pm 0,5773$ & \\
\hline & & 6 & $21,000 \pm 0,816$ & \\
\hline & & 12 & $21,500 \pm 0,577$ & \\
\hline & & 24 & $23,750 \pm 0,500$ & \\
\hline & & 48 & $25,000 \pm 0,000$ & \\
\hline & & 72 & $25,000 \pm 0,000$ & \\
\hline 4 & $\begin{array}{l}\text { F3 : Solanum melongena } L \text { dan } \\
\text { Cananga adorata }(2: 1)\end{array}$ & 1 & $1,750 \pm 0,500$ & \\
\hline
\end{tabular}




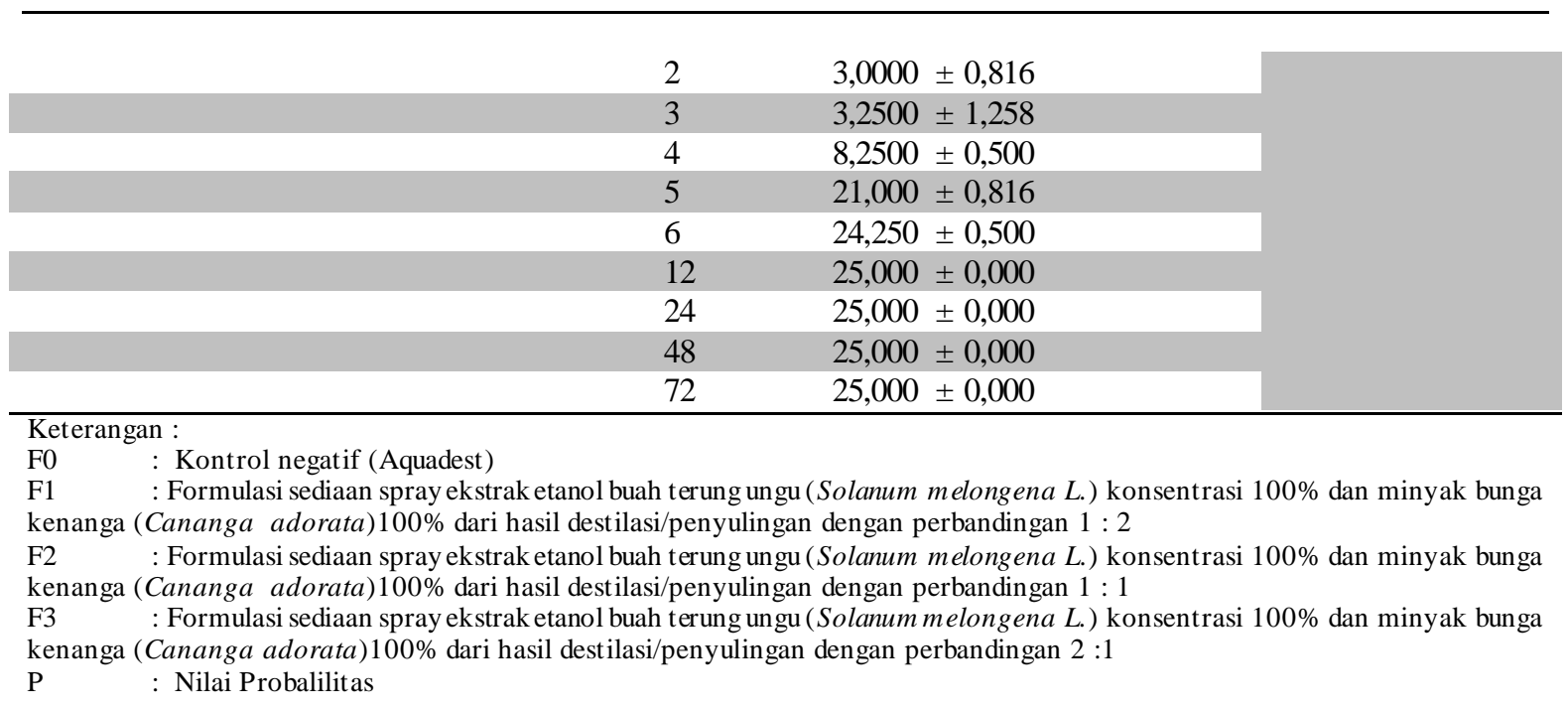

Berdasarkan tabel 2 menunjukkan perbandingan Solanum melongena L dan Cananga adorata, waktu kontak serta perbandingan konsentrasi dan waktu kontak menunjukkan nilai signifiknsi (p) sebesar $0,0000<$ $\alpha 0,05$ artinya variasi kombinasi formulasi dan waktu kontak berpengaruh terhadap kematian larva nyamuk. Selisih nilai rata-rata kematian larva pada masing - masing konsentrasi mengalami peningkatan berdasarkan urutan F0, F1, F2, dan F3. Hal tersebut menunjukkan bahwa konsentrasi efektif berada pada Formulasi sediaan spray ekstrak etanol buah terung ungu (Solanum melongena L.) konsentrasi 100\% dan minyak bunga kenanga (Cananga adorata)100\% dari hasil destilasi/penyulingan dengan perbandingan $2: 1$.

\section{Pembahasan}

Pemanfaatan senyawa-senyawa bioinsektisida dari bahan - bahan alam relatif aman bagi lingkungan dan manusia karena bahan alami yang berasal dari tumbuhan memiliki sifat mudah terurai di lingkungan (biodegradable) sehingga residunya cepat menghilang, berbeda dengan insektisida sintetik yang bersifat sulit terurai di alam sehingga akan mencemari lingkungan dan mempengaruhi organisme lain. Penelusuran literature terhadap bahan - bahan alam yang secara ilmiah terbukti sebagai bioinsektisida yaitu tumbuhan Babadotan, Bunga kenanga dan rimpang lengkuas putih. Dari tumbuhan babadotan diperoleh fraksi aktif berupa fraksi $n$-heksan dan etilasetat. Dari bunga kenanga diperoleh fraksi aktif berupa fraksi $n$-heksan dan etilasetat, sedangkan dari rimpang lengkuas putih diperoleh fraksi aktif berupa fraksi $\mathrm{n}$-heksana (Erwin $\mathrm{N}$, dkk 2013). Dalam penelitian ini untk mengombinasikan hasil penelitian terdahulu yang menggunakan ekstrak terungu ungu dengan tujuan selain memberikan efek wangi pada formulasi juga secara ilmiah terbukti sebagai bioinsektisida maka dipilih bunga kenanga dalam bentuk sediaan minyak atsiri yang memberikan efek wangi yang tajam. Fungsi minyak atsiri pada tanaman adalah memberi bau untuk membantu penyerbukan, media distribusi ke biji, dan penolak nyamuk.

Minyak atsiri merupakan bahan aktif yang mempunyai kemampuan untuk menolak nyamuk yang mendekati manusia. Penelitian ekstrak bunga kenanga (Canangium odoratum) mempunyai efektivitas larvasida pada larva Ae. aegypti menunjukkan hasil pada konsentrasi 0,02\% kematian larva uji mencapai 96\% di jam ke-24, hasil uji Mann-Whitney bahwa antara kelompok kontrol dengan semua konsentrasi memiliki perbedaan jumlah kematian larva yang secara statistik signifikan. Konsentrasi 0,02\% sangat efektif dalam membunuh larva nyamuk Ae.aegypti.

Hasil uji Mann-Whitney untuk lama kontak didapatkan bahwa lama kontak 24 jam memiliki pengaruh yang sangat signifikan terhadap kematian larva Ae.aegypti. Nilai LC50 menunjukkan penurunan nilai konsentrasi seiring peningkatan waktu (jam ke 4-24) yaitu 0,133\% sampai dengan 0,001\%. Untuk nilai LC90 yaitu $0,008 \%$. Sedangkan nilai LT50 menunjukkan penurunan waktu yang dibutuhkan seiring peningkatan konsentrasi (0,0025\%-0,02\%) yaitu dari 15,076 jam sampai 6,701 jam (Listya P, 2014). Bahan alam lain yang berasal dari tanaman yang sekaligus dapat dimanfaatkan sebagai sayur, mudah didapatkan masyarakat dan belum banyak diteliti untuk larvasida adalah adalah buah terung ungu. Buah terung ungu merupakan buah yang berasal dari genus Solanum, mengandung zat aktif yang dapat dimanfaatkan sebagai insektisida. Berdasarkan teori buah terung ungu diketahui banyak mengandung alkaloid steroid (solasodine, solanine, solanidine), saponin, flavonoid, tanin, kumarin. Kulit buah terung ungu banyak mengandung antosianin serta as am klorogenat (Suhandoyo, Astuti, \& Ratnawati, 2013). 
Berdasarkan penelitian Saleh (2015) ekstrak etanol buah terung ungu (Solanum melongena) yang diekstrak menggunakan metode maserasi mengandung flavonoid, tanin, glikosida, steroid dan alkaloid. Formulasi kombinasi antara ekstrak etanol buah terung ungu dan minyak bunga kenanga (Cananga adorata) terutama mengetahui efektivitasnya atau pengaruhnya dalam mematikan nyamuk Aedes $S p$ berdasarkan variasi waktu kontak dan nilai $\mathrm{LC}_{50}$,nilai $\mathrm{LC}_{90}$ merupakan tujuan dari penelitian ini. Penelitian ini menggunakan 3 perlakuan dan 1 kontrol negatif. Jenis perlakuan dibedakan dengan variasi kombinasi formulasi sediaan spray ekstrak etanol $96 \%$ buah terung ungu dengan konsentrasi $100 \%$ dan minyak bunga kenanga $100 \%$ dari hasil destilasi/penyulingan. Intervensi menggunakan formulasi sediaan spray ekstrak etanol buah terung ungu (Solanum melongena L.) konsentrasi 100\% dan minyak bunga kenanga (Cananga adorata)100\% dari hasil destilasi/penyulingan dengan perbandingan $1: 2,1: 1$ dan $2: 1$. Uji hayati pengamatan kematian nyamuk di laboratorium dilakukan menurut ketentuan WHO.

Pengamatan dilakukan berdasarkan variasi waktu kontak 1 jam, 2 jam, 3 jam, 4 jam, 5 jam, 6 jam, 7 jam, 8 jam, 9 jam, 10 jam, 11 jam, 12 jam, 24 jam, 48 jam dan 72 jam setiap perlakuan dan kontrol. Porsentase kematian nyamuk dihitung setelah pemaparan perlakuan dan kontrol 1 jam, 2 jam, 3 jam, 4 jam, 5 jam, 6 jam, 7 jam, 8 jam, 9 jam, 10 jam, 11 jam, 12 jam, 24 jam, 48 jam dan 72 jam. Kombinasi formulasi sediaan spray ekstrak etanol buah terung ungu (Solanum melongena L.) konsentrasi 100\% dan minyak bunga kenanga (Cananga adorata)100\% dari hasil destilasi/penyulingan dengan perbandingan $1: 2,1: 1$ dan 2 : 1 dikatakan efektif apabila dapat mematikan larva nyamuk di atas $80 \%$ pada pengamatan 72 jam. Untuk memperoleh waktu untuk mematikan separuh dan 95\% populasi dianalisa dengan prediksi interval variasi waktu kontak yang menyebabkan kematian nyamuk Aedes $S p$. Apabila pada pengamatan 72 jam kelompok kontrol terdapat kematian 5 - 20\% maka persentase kematian nyamuk dikoreksi dengan rumus Abbot, dan apabila kematian kontrol di atas $20 \%$ maka uji diulang (WHO,.2014).

Hasil penelitian menunjukkan bahwa kematian nyamuk Aedes sp setelah terpapar larutan formulasi F1 sediaan spray ekstrak etanol buah terung ungu (Solanum melongena L.) konsentrasi 100\% dan minyak bunga kenanga (Cananga adorata) konsentrasi 100\% dari hasil destilasi/penyulingan dengan perbandingan $1: 2$ yaitu $5 \mathrm{ml}$ ekstrak etanol buah terung ungu (Solanum melongena L.) konsentrasi 100\% dan 10 ml minyak bunga kenanga (Cananga adorata) konsentrasi 100\% dari hasil destilasi/penyulingan mulai menunjukkan kematian setelah terpapar selama 2 jam. Jumlah dan porsentase kematian nyamuk Aedes sp secara berturut turut berdasarkan variasi waktu kontak adalah $0(0 \%)$ pada lama paparan 1 jam, 10 (10\%) pada lama paparan 2 jam, 15 (15\%) pada lama paparan 3 jam, 18 (18\%) pada lama paparan 4 jam, 32 (32\%) pada lama paparan 5 jam, $86(86 \%)$ pada lama paparan 6 jam, 92 (92\%) pada lama paparan 12 jam, $100(100 \%)$ pada lama paparan 24 jam, $100(100 \%)$ pada lama paparan 48 jam dan 100 (100\%) pada lama paparan 72 jam. F2 sediaan spray ekstrak etanol buah terung ungu (Solanum melongena L.) konsentrasi 100\% dan minyak bunga kenanga (Cananga adorata) konsentrasi 100\% dari hasil destilasi/penyulingan dengan perbandingan $1: 1$ yaitu 7,5 ml ekstrak etanol buah terung ungu (Solanum melongena L.) konsentrasi 100\% dan 7,5 ml minyak bunga kenanga (Cananga adorata) konsentrasi 100\% dari hasil destilasi/penyulingan mulai menunjukkan kematian setelah terpapar setama 2 jamr.

Jumlah dan porsentase kematian nyamuk Aedes $s p$ secara berturut - turut berdasarkan variasi waktu kontak adalah $0(0 \%)$ pada lama paparan 1 jam, $9(9 \%)$ pada lama paparan 2 jam, 13 (13\%) pada lama paparan 3 jam, $16(16 \%)$ pada lama paparan 4 jam, 30 (30\%) pada lama paparan 5 jam, 84 (84\%) pada lama paparan 6 jam, $86(86 \%)$ pada lama paparan 12 jam, 95 (95\%) pada lama paparan 24 jam, 100 (100\%) pada lama paparan 48 jam dan 100 (100\%) pada lama paparan 72 jam. F3 sediaan spray ekstrak etanol buah terung ungu (Solanum melongena L.) konsentrasi $100 \%$ dan minyak bunga kenanga (Cananga adorata) konsentrasi 100\% dari hasil destilasi/penyulingan dengan perbandingan $1: 1$ yaitu 7,5 ml ekstrak etanol buah terung ungu (Solanum melongena L.) konsentrasi 100\% dan 7,5 ml minyak bunga kenanga (Cananga adorata) konsentrasi $100 \%$ dari hasil destilasi/penyulingan mulai menunjukkan kematian setelah terpapar selama 1 jam. Jumlah dan porsentase kematian nyamuk Aedes $s p$ secara berturut - turut berdasarkan variasi waktu kontak adalah 7 (7\%) pada lama paparan 1 jam, $12(12 \%)$ pada lama paparan 2 jam, $17(17 \%)$ pada lama paparan 3 jam, 33 (33\%) pada lama paparan 4 jam, 84 (84\%) pada lama paparan 5 jam, 97 (97\%) pada lama paparan 6 jam, $100(100 \%)$ pada lama paparan 12 jam, $100(100 \%)$ pada lama paparan 24 jam, 100 (100\%) pada lama paparan 48 jam dan 100 (100\%) pada lama paparan 72 jam. Kelompok kontrol negative yang di spray dengan aquadest menunjukkan dari paparan 1 jam sampai 72 jam tidak menunjukkan adanya kematian nyamuk Aedes $S p$.

Hasil penelitian juga menunjukkan bahwa pada formulasi F1 Letal Concentration 50\% (LC50) dan Letal Concentration 90\% (LC90) terdapat pada interval waktu kontak 5 jam dengan 6 jam, dimana pada waktu kontak 5 jam terdapat 32\% kematian nyamuk dan waktu kontak 6 jam terdapat $92 \%$ kematian nyamuk. 
Formulasi F2 Letal Concentration 50\% (LC50) dan Letal Concentration 90\% (LC90) juga terdapat pada interval waktu kontak 5 jam dengan 6 jam, dimana pada waktu kontak 5 jam terdapat 32\% kematian nyamuk dan waktu kontak 6 jam terdapat 96\% kematian nyamuk. Formulasi F3 Letal Concentration 50\% (LC50) terdapat pada interval waktu kontak 4 jam dengan 5 jam, dimana pada waktu kontak 4 jam terdapat 33\% kematian nyamuk dan waktu kontak 5 jam terdapat $84 \%$ kematian nyamuk. Letal Concentration 90\% (LC90) terdapat pada interval waktu kontak 5 jam dengan 6 jam, dimana pada waktu kontak 5 jam terdapat $84 \%$ kematian nyamuk dan waktu kontak 6 jam terdapat 97\% kematian nyamuk. Berdasarkan hasil uji statistik One Way Anova menunjukkan perbandingan Solanum melongena L dan Cananga adorata, waktu kontak serta perbandingan konsentrasi dan waktu kontak menunjukkan nilai signifiknsi (p) sebesar 0,0000< $\alpha 0,05$ artinya variasi kombinasi formulasi dan waktu kontak berpengaruh terhadap kematian larva nyamuk.

Selisih nilai rata-rata kematian larva pada masing - masing konsentrasi mengalami peningkatan berdasarkan urutan F0, F1, F2, dan F3. Hal tersebut menunjukkan bahwa konsentrasi efektif berada pada Formulasi sediaan spray ekstrak etanol buah terung ungu (Solanum melongena L.) konsentrasi 100\% dan minyak bunga kenanga (Cananga adorata) $100 \%$ dari hasil destilasi/penyulingan dengan perbandingan $2: 1$. Hasil penelitian yang telah berhasil membuktikan bahwa formulasi sediaan spray ekstrak etanol buah terung ungu (Solanum melongena L.) konsentrasi 100\% dan minyak bunga kenanga (Cananga adorata) $100 \%$ dari hasil destilasi/penyulingan yang memberikan efek formulasi yang wangi dan efektif sebagai bioinsektisida mematikan nyamuk Aedes Sp, didukung oleh beberapa penelitian terdahulu antara lain hasil penelitian Nofyan \& Marisa, (2013) membuktikan bahwa ekstrak kenanga efektif sebagai replensia nyamuk Culex $s p$ $(A, n . d$.$) dari bunga kenanga diperoleh fraksi aktif berupa fraksi \mathrm{n}$-heksan dan etil asetat.

Hasil uji-T menunjukan bahwa mortalitas larva nyamuk Ae. aegypti yang disemprot ekstrak bunga kenanga signifikan lebih tinggi dibandingkan mortalitas larva nyamuk Ae. aegypti yang disemprot ekstrak daun bandotan. Hasil penelitian yang telah berhasil membuktikan efektivitas formulasi kombinasi sediaan spray ekstrak etanol buah terung ungu (Solanum melongena L.) konsentrasi $100 \%$ dan minyak bunga kenanga (Cananga adorata) $100 \%$ dari hasil destilasi/penyulingan karena kandungan zat - zat bioaktif dari kedua bahan alam ini. Bunga kenanga diketahui mengandung geraniol yang bersifat toksik sebagai racun kontak, Geraniol merupakan salah satu jenis minyak atsiri yang mempunyai sifat seperti alkohol biasa yaitu bersifat antiseptik atau bakteriostatik. Sifat antiseptik dan bakteriostatik berarti menyerap oksigen $\left(\mathrm{O}_{2}\right)$ sehingga binatang atau larva nyamuk bis a mati karena kekurangan oksigen karena geraniol sifatnya menyerap oksigen (Indriati dan Amilah, 2014).

Kenanga mampu mengusir nyamuk karena baunya yang harum dan khas yang tidak disukai oleh nyamuk serta karena adanya kandungan geraniol, linalol, daneugenol (Widyastuti \& Jannah, 2015). Bunga Kenanga (Cananga odorata) dapat menyebabkan kematian larva Ae. aegypti karena terdapat zat-zat atau senyawa yang dapat mematikan larva Aedes aegypti, beberapa zat atau senyawa yang berperan penting di dalam bunga kenanga dalam mematikan larva Aedes aegypti yaitu minyak atsiri saponin, flavonoida dan poilifenol (Widyastuti \& Jannah, 2015). Sedangkan daya toksik yang ditimbulkan oleh ekstrak terung ungu (Solanum melongena L.) disebabkan karena adanya beberapa bahan aktif yang terkandung dalam ekstrak tersebut sehingga dapat menyebabkan kematian pada nyamuk Aedes sp. Beberapa senyawa bioaktif yang diduga terkandung pada ekstrak terung ungu di antaranya adalah flavonoid, saponin, glikoalkaloid dan tanin yang terbukti bersifat racun kontak dan racun pernafas an pada serangga khususnya nyamuk Aedes sp. Senyawa flavonoid merupakan golongan fenol dan banyak ditemukan di dalam tumbuhan.

Penelitian lain yang menggunakan bunga kenanga dan bunga kamboja kuning, dapat berfungsi sebagai penolak nyamuk karena digunakan tanaman bunga kenanga dan kamboja kuning karena tanaman ini mengandung minyak atsiri yang (Hidayati, Suhirman, \& Wahyudiati, n.d.). Hasil penelitian Anis N (2018) yang menggunakan buah terung ungu berbentuk oval yang berasal dari perkebunan s ayur desa Sembalun Lombok Timur membuktikan bahwa ekstrak buah terung ungu (Solanum melongena L.) disemprotkan ke dalam sangkar nyamuk yang berisi 25 ekor nyamuk Aedes sp. berumur $2-5$ hari yang didiamkan selama 24 jam, menunjukan hasil konsentrasi ekstrak etanol buah terung ungu (Solanum melongena L.) 80\% menyebabkan $84 \%$ kematian nyamuk Aedes sp. Konsentrasi ekstrak etanol buah terung ungu (Solanum melongena L.) $60 \%$ menyebabkan 68\% kematian nyamuk Aedes sp. Konsentrasi ekstrak etanol buah terung ungu (Solanum melongena L.) $40 \%$ menyebabkan $44 \%$ kematian nyamuk Aedes sp.

Hasil penelitian Anis N (2018) juga membuktikan toksisitas ekstrak terung ungu (Solanum melongena L.) terhadap nyamuk Aedes sp memiliki estimasi nilai $\mathrm{LC}_{50}$ pada konsentrasi $49.124 \%$ dan nilai LC 90 pada konsentrasi $81.343 \%$ tetapi hasil penelitian ini belum diketahui secara pasti zat bioaktif yang terdapat dari ekstrak etanol $96 \%$ buah terung ungu (Solanum melongena L.) yang berasal dari perkebunan sayur desa 
Sembalun Lombok Timur dan belum ada data kuantitatif antara waktu kontak per jam dengan jumlah kematian nyamuk Aedes sp., Hasil penelitian Zaenal F, dkk (2018) menunjukkan bahwa zat bioaktif yang terdapat dari ekstrak etanol $96 \%$ buah terung ungu (Solanum melongena L.) yang berasal dari perkebunan sayur desa Sembalun Lombok Timur adalah Tannin Total Ekuivalen 4,11 \% b/b, total alkaloid ekuivalen quinine 100,22 ug/g dan total flavonoid ekuivalen rutin adalah 3,55\% \%/b, hasil penelitian juga membuktikan bahwa dalam waktu 1 jam dari waktu kontak spray ekstrak etanol $96 \%$ buah terung ungu dengan nyamuk Aedes sp menunjukkan kematian 50\% dari 25 ekor nyamuk yang diujikan, mencapai kematian $75 \%$ setelah 6 jam dan mencapai kematian $100 \%$ setelah 24 jam dari waktu kontak.

Persentase kematian nyamuk berbanding lurus dengan konsentrasi yaitu semakin tinggi konsentrasi ekstrak maka persentase kematian juga akan semakin tinggi. Hal ini disebabkan karena semakin tinggi konsentrasi yang digunakan maka semakin tinggi pula kandungan bahan aktif yang ada pad a ekstrak. Secara umum fungsi dan efektivitas insektisida berbanding lurus yang artinya semakin tinggi dosis/konsentrasi insektisida maka semakin tinggi pula peluang dalam mengendalikan serangga. Meskipun belum ada penelitian yang secara langsung menjelaskan dampak penggunaan insektisida alami terhadap kesehatan manusia, pengaplikasian hasil penelitian ini di lingkungan harus tetap terkendali. Untuk saat ini penggunaan insektisida alami merupakan suatu alternatif pengendalian serangga rumah tangga secara aman dan membantu meminimalkan risiko lingkungan.

\section{Kesimpulan}

Perbandingan formulasi kombinasi sediaan spray ekstrak etanol buah terung ungu (Solanum melongena L.) konsentrasi $100 \%$ dan minyak bunga kenanga (Cananga adorata)100\% dari hasil destilasi/penyulingan berdasarkan waktu kontak serta perbandingan konsentrasi dan waktu kontak menunjukkan nilai signifiknsi (p) sebesar $0,0000<\alpha 0,05$ artinya variasi kombinasi formulasi dan waktu kontak berpengaruh terhadap kematian larva nyamuk. Selisih nilai rata-rata kematian larva pada masing masing konsentrasi mengalami peningkatan. Hal tersebut menunjukkan bahwa konsentrasi efektif berada pada formulasi sediaan spray ekstrak etanol buah terung ungu (Solanum melongena L.) konsentrasi 100\% dan minyak bunga kenanga (Cananga adorata)100\% dari hasil destilasi/penyulingan dengan perbandingan 2 :1. Formulasi F1 Letal Concentration 50\% (LC50) dan Letal Concentration 90\% (LC90) terdapat pada interval waktu kontak 5 jam dengan 6 jam, dimana pada waktu kontak 5 jam terdapat 32\% kematian nyamuk dan waktu kontak 6 jam terdapat 92\% kematian nyamuk. Formulasi F2 Letal Concentration 50\% (LC50) dan Letal Concentration 90\% (LC90) juga terdapat pada interval waktu kontak 5 jam dengan 6 jam, dimana pada waktu kontak 5 jam terdapat 32\% kematian nyamuk dan waktu kontak 6 jam terdapat $96 \%$ kematian nyamuk.

Formulasi F3 Letal Concentration 50\% (LC50) terdapat pada interval waktu kontak 4 jam dengan 5 jam, dimana pada waktu kontak 4 jam terdapat 33\% kematian nyamuk dan waktu kontak 5 jam terdapat $84 \%$ kematian nyamuk. Letal Concentration 90\% (LC90) terdapat pada interval waktu kontak 5 jam dengan 6 jam, dimana pada waktu kontak 5 jam terdapat 84\% kematian nyamuk dan waktu kontak 6 jam terdapat $97 \%$ kematian nyamuk. Formulasi kombinasi sectraan spray ekstrak etanot buah terung ungu (Solantm metongenta L.) konsentrasi 100\% dan minyak bunga kenanga (Cananga adorata)100\% dari hasil destilasi/penyulingan sangat efektif dalam mematikan nyamuk Aedes $S p$.

\section{Daftar Pustaka}

Agoreyo, B. O., Obansa, E. S., \& Obanor, E. O. (2012). Comparative Nutritional and Phytochemical Analyses of Two Varieties of Solanum melongena. Sciece World Jurnal, 7(1), 5-8.

Akbar, M. (2011). Perbedaan Efikasi Antara Campuran Transfluthrin dan Cyfluthrin Spray Dengan Campuran Permethrin dan Prallethrin Spray Terhadap Nyamuk Aedes aegypti. Skripsi.

Amilah, I. S. (2014). Aktivitas Larvasida Ekstrak Daun Bandotan ( Ageratum conyzoides L .) Dan Bunga Kenanga ( Cananga odorata L. ) Terhadap Nyamuk Demam Berdarah ( Aedes Aegypti L.), 07(02), 24-27.

Anis N,(2018). Pemanfaatan Ekstrak Etanol Buah Terung Ungu (Solanum melongena L.) Sebagai Insektisida Nyamuk Aedes sp.Skripsi Prodi D.IV Analis Kesehatan Politeknik Kesehatan Kemenkes Mataram.

Arivia, S. (2006). Efek Larvasida Ekstrak Daun Lidah Buaha (Aloe vera) Terhadap Larva Nyamuk Aedes aegypti Instar III. Skripsi. 
Dinas Kesehatan Provinsi NTB. (2017). Profil Kesehatan Provinsi Nusa Tenggara Barat Tahun 2016. Mataram: Dinas Kesehatan Provinsi NTB.

Erlina, R. (2015). Uji Efektivitas Ekstrak Daun Zodia (Evodia suaveolens) Dalam Sediaan Lotion Dengan Basis PEG 400 Sebagai Repellent Terhadap Aedes aegypti. Skripsi.

Fadlia, N. (2011). Efek Diuresis Jus Terung Ungu (Solanum melongena L.) Terhadap Tikus Putih Jantan (Rattus norvegicus). Skripsi.

Fajriyatun, B. N. (2013). Uji Efek Pemberian Ekstrak Etanol 70\% Biji Buah Terung Ungu (Solanum melongena L.) Terhadap Kadar Kolesterol HDL Serum Darah Tikus Putih Jantan (Rattus novergicus) Galur Wistar. Skripsi.

Fatmawati, T. (2014). Distribusi dan Kelimpahan Larva Nyamuk Aedes spp. di Kelurahan Sukorejo Gunungpati Semarang Berdasarkan Peletakan Ovitrap. Skripsi.

Gandahusada, S., Ilahude, H. D., \& Pribadi, W. (2006). Parasitologi Kedokteran (Edisi keti). Jakarta: Balai Penerbit FKUI.

Handito, S. (2015). Uji Efektivitas Ekstran Daun Cengkeh (Syzygium aromaticum L.) Sebagai Bahan Dasar Obat Nyamuk Elektrik Cair terhadap Nyamuk Aedes aegypti. Skripsi.

Hidayati, A. U., Suhirman, \& Wahyudiati, D. (n.d.). Pengaruh Ekstrak Bunga Kenanga (Canangium odoratum) Dan Bunga Kamboja Kuning (Plumeria acuminata) Terhadap Mortalitas Nyamuk Rumah (Culex quenquiefasciatus) Ana.

Islamiyati, R. (2013). Uji Aktivitas Antioksidan pada Buah Terung Ungu dan Terung Hijau Menggunakan Metode Peredaman Radikal Bebas DPPH. Skripsi, 8-9.

Kemenkes RI. (2016). Info DATIN DBD (Pusat Data dan Informasi Kementerian Kesehatan RI). Jakarta Selatan: Kementerian Kesehatan RI.

Kuraga, R. D. (2011). Keberadaan Larva Nyamuk Aedes sp. Dalam Container Tempat Penampungan Air (TPA) Sebelum dan Sesudah Penyuluhan di Desa Ciwaru, Kecamatan Bayah, Jawa Barat. Skripsi.

Musdalifah. (2016). Uji Efektivitas Ekstrak Kulit Buah Jeruk Nipis (Citrus aurantifolia) Sebagai Insektisida Hayati Terhadap Aedes aegypti. Skripsi. Makassar: Fakultas Kedokteran dan Ilmu Kesehatan UIN Alauddin Makassar.

Nofyan, E., \& Marisa, H. (2013). Pengendalian Larva Nyamuk Aedes aegypti di Sumatera Selatan, $275-282$.

Notoatmodjo, S. (2012). Metodologi Penelitian Kesehatan. Jakarta: Rineka Cipta.

Paranitasari, L. (2014). Efektivitas Ekstrak Bunga Kenanga(Canangiumodoratum) Sebagai Larvasida Pada Larva Aedes aegypti.

Putu, N., Asri, W., Pratini, P., Jiwantoro, Y. A., \& Khusuma, A. (2019). Perbedaan Kadar Kolesterol Total Menggunakan Antikoagulan EDTA ( $\mathrm{CH} 2 \mathrm{CO} 2 \mathrm{H}$ ), Natrium Sitrat ( Na 3 C $6 \mathrm{H} 5 \mathrm{O} 7$ ), dan Natrium. 6(2).

Safwan, W., A., \& Adikusuma, W. (2016). Petunjuk Praktikum Fitokimia. Mataram: Universitas Muhammadiyah Mataram.

Saleh, G. S. (2015). Chemical Detection of some Active Compounds in Egg Plant (Solanum melongena) Callus as Compared with Fruit and Root Contents. International Journal of Current Microbiology and Applied Sciences, 4(5), 160-165. 
ISSN: 2656-2456 (Online)

ISSN: $2356-4075$ (Print)

Septyarini, K. V. (2017). Pengaruh Lama dan Suhu Pengeringan Terhadap Sifat Fisik dan Kimiawi Tepung Terung Ungu (Solanum melongena L.). Skripsi, 4-19.

Suhandoyo, Astuti, \& Ratnawati. (2013). Pemanfaatan Tepung Terong Ungu (Solanum melongena L.) Untuk Menurunkan Kadar Lemak, LDL dan Kadar Kolesterol Ayam Broiler Strain Lohmann. Skripsi.

Suryani, D. P. A. (2015). Uji Efektifitas Ekstrak Etanol Bunga Krisan (Chrysanthemum morifolium) Sebagai Larvasida Terhadap Larva Aedes Aegypti Instar III. Skripsi, 8-30.

Utomo, M. (2010). Pengaruh Jumlah Air yang Ditambahkan pada Kemasan Serbuk Bunga Sukun (Artocarpus communis) sebagai Pengganti Isi Ulang (Refill) Obat Nyamuk Elektrik Terhadap Lama Waktu Efektif Daya Bunuh Nyamuk Anopheles aconitus Lapangan. Skripsi.

WHO. (2014). Dengue and Severe Dengue. Retrieved February 12, 2018, from http://www.who.int/mediacentre/factsheets/fs 117/en/

Widyastuti, R., \& Jannah, W. (2015). Pengaruh Konsentrasi Rebusan Bunga Kenanga (Cananga odorata) Terhadap Kematian Larva Aedes aegypti, 4(2), 284-288. 